\title{
Surfaces
}

\section{TRANSLATIO AND COMPARATIVE LITTERATURE: THE TERROR OF EUROPEAN HUMANISM}

\section{Bill Readings}

Volume 1, 1991

URI : https://id.erudit.org/iderudit/1065259ar

DOI : https://doi.org/10.7202/1065259ar

Aller au sommaire du numéro

Éditeur(s)

Les Presses de l’Université de Montréal

ISSN

1188-2492 (imprimé)

1200-5320 (numérique)

Découvrir la revue

Citer cet article

Readings, B. (1991). TRANSLATIO AND COMPARATIVE LITTERATURE: THE TERROR OF EUROPEAN HUMANISM. Surfaces, 1.

https://doi.org/10.7202/1065259ar
Résumé de l'article

L'importance de la littérature comparée comme découlant de sa relation dédoublée à la fonction de traduction. Critique de la terreur menée par l'humanisme européen et insistance sur la lecture minoritaire de la littérature, sur la traduction comme rencontre avec la différence. 
TRANSLATIO AND COMPARATIVE LITTERATURE:

THE TERROR OF EUROPEAN HUMANISM

Bill Readings

\begin{abstract}
The interest of comparative literature as its divided relation to the function of translation. Critique of the terror of European humanism and insistence on the minoritarian reading of literature, on translation as an encounter with difference.
\end{abstract}

\title{
RÉSUMÉ
}

L'importance de la littérature comparée comme découlant de sa relation dédoublée à la fonction de traduction. Critique de la terreur menée par l'humanisme européen et insistance sur la lecture minoritaire de la littérature, sur la traduction comme rencontre avec la différence.

My aim in this paper is a slightly tricky one. On the one hand, I want to maintain a critique of nationalism in literary study. At the same time, however, I want to argue against that particular European form of supranationalism that has traditionally animated the quasi-discipline of 
comparative literature. In order to do this, I want to suggest that the value of comparative literature has always been its failure. This failure proceeds from the fact that it has named a certain pocket or reserve within literary studies, an uncertainty as to whether it compares nationalities, transcends them, or does something slightly more difficult -- namely worries over (and at) the differences that the nationalistic study of literature (and there has been no other kind, since the concept of literature arose as a secular form along with the nation state) seeks to establish as its fixed frontiers, beyond discussion. One name for this worry will turn out to have been "translation." In a sense, the work of translation that at first seemed to ground an international comparison will turn out to have been the problem that animated our discussions anyway, their interminable goal.

As in some small way a student of the Renaissance, I have found my work, though largely conducted in English departments, necessarily comparativist because the idea of Renaissance remains inseparable from the image of a still to be accomplished European community. The quasi-discipline of comparative literature, if it has been largely devoted to the continuation of that integrationist project of translation, has also been the site of another work of translation -- that of literary theory. A double translation from French and German into English, from philosophy to literature. Taking the problems of translation seriously, I want to speak of a disparate field of literary study, in some important sense comparativist, in order to tell you a few little stories. First, how comparative literature may become the field for and of literary theory. Second, what the impact of literary theory may be on the traditional modes of inquiry on comparative literature. Third, why I think we should now try to move to a study of differentiated literature, a study which should make us suspicious of the spectre of universalism (or unification) that is now haunting Europe. This will be, at the same time, a small allegory of deconstruction in the new world. /pp 5-6/

The study of comparative literature takes off from the idea of humanity. Its links with nationalism have always been a matter for discussion: Mussolini, for example, effectively banned comparative studies since Italian was the only inheritor of the Roman tradition worthy of the name. The great betrayal of the post-war constitution in Italy, in which the PCI collaborated with the Christian Democracy, was the suppression of anticipated regional autonomy and, a fortiori, linguistic diversity. There has also been an Hegelian tendency to rewrite European literary history as the becoming-German of all worthwhile literature -- something that one can find in the Nazi journalism of the young Paul de Man. The English have used Shakespeare in place of Hegel to invent the history of literature as the struggle to become British and escape from French formalism. The common thread of all these separate histories is the pretension to personify in the best manner possible the general idea of humanity.

The important shift of our time is that comparative literature is becoming the site where an idea of literature can be worked out that is not at all 
universalist, that is not a new world order. In its place, we are trying to develop a patchwork (one might say "quilt" in allusion to the possible gender coordinates of this attempt) of minor literatures, in the sense of the term employed by Deleuze and Guatarri in their studies of Kafka:

A minor literature isn't written in a minor language: it is rather that which a minority constructs within a major language. But the first characteristic of minor literature in any case is that in it language is affected by a high coefficient of deterritorialization. In this sense, Kafka marks the impasse that bars access to writing for the Jews of Prague and turns their literature into something impossible -- the impossibility of not writing, the impossibility of writing in German, the impossibility of writing otherwise.[1]

/pp 6-7/

Separatist movements of all kinds, in so far as they are minoritarian, form part of a loss of belief in the grand narrative of humanity and its liberation proposed to us by the Enlightenment, whether they are struggling for the rights of aborigines in "New Worlds", whether arising out of the dissolution of the Russian Empire, whether fighting for the right of homosexuals to affirm their difference.

Limiting myself to the literary question, I'd like to characterize the postmodernity of comparative literature not as a new epoch but as the realization that the literary thing, writing, cannot be limited to the expression or mimetic reflection of the human spirit or the human condition, as romanticism and classicism have respectively claimed. And that's not because literature exceeds the human so as to offer us a glimpse of the absolute, of a real totality as George Steiner might say. The literary thing remains minor, resists understanding, resists reading as a human activity. This will not have been mysticism.

Deleuze and Guattari phrase this resistance to understanding as the problem of writing for Kafka in all its necessity ("impossibility of not writing... impossibility of writing otherwise") and impossibility (impossibility of writing in German). The great work of Paul de Man in the field of comparative literature was to remind us that reading always found itself caught in this double bind: the simultaneity of necessity and impossibility in the act of reading. One must read but can never make of reading a completed act. Here I might allude to his remarks in Blindness and Insight on repetition and difference in immanent critique[2]. It is along similar lines that I wish to speak of the literary thing as the site of a "differend", as JeanFrançois Lyotard puts it. 
There are many ways of noting how literary reading has become the attempt to bear witness to differends. One might, for example, speak of how Eurocentrism of the comparativist tradition has been shaken following the decolonization of the Third World. This is not merely because we are finally beginning to notice the existence of literatures outside Europe. More importantly, we are perhaps beginning to learn the hard lesson that not only our European account of humanity was ethno-centric -- the very notion of a general idea of humanity was itself only a part of the universalizing and totalizing tradition of modern western thought. In his film Where the Green Ants Dream, Werner Hertzog shows how the notion of an abstract concept of humanity is itself an imperialist imposition on Australian aborigines of the privilege that white men give to the bleached whiteness of abstracted thought.[3]

A white mythology. The West thinks the human subject as essentially an immigrant in its relation to a world that it seeks to master through ingenuity. The presupposition of an abstract humanity common to all people can only oppress the singularity of the link between the Australian aborigine and the land, a link that is foreign to any abstraction, that cannot be transposed or translated into another place.

In considering them human, the white man misrecognizes the singularity of the aborigines --oppresses them in the very attempt to insure their "human rights." The bankruptcy of the imperialist mission civilisatrice as such (and not merely because of the incidental violence of its executives) puts us face to face with a difference that cannot be made part of consciousness: the difference of beings that do not understand their humanity in the same way as "us," who do not wish to become part of the crew of the Starship Enterprise, flagship of Western capitalist modernity. People /pp 8-9/ whom we silence in the very act of giving them the right to speak in the language of the human spirit, in the very act of liberating them from their local and minoritarian superstitions. We would have to change our idea of comparative literature to speak of minoritarian voices that do not wish to arrive at their majority. And this is not only a problem which appears from outside the European tradition of comparative literature. As Lyotard reminds us:

What is most real about the actual Jews is that Europe at least doesn't know what to do with them. Christian Europe demands their conversion, monarchic Europe expels them, Republican Europe integrates them, Nazi Europe exterminates them. "The Jews" are the object of the non-place by which the Jews in particular are really affected. They are the population of 
souls which the writing of Kafka, for example, in an exemplary fashion, has only sheltered so as to better expose them to their condition as hostages.[4]

Under the name of Kafka in literature, under the name of Auschwitz in philosophy, an inquiry has been undertaken into a minoritarian thing, a heterogeneity which cannot be harmonized with the grand narrative of the realization of the universal idea of humanity, a discord with the modern mode of temporal organization. I say temporal because this minor thing comes back to us like a phantom -- a soul (psyche) that one can neither forget nor remember so that literature always appears to us heteronomous, "ghost written" so to speak[5]. Here we brush up against Freud's work on the problematic temporality of the unconscious and the "belatedness" of consciousness which still remains the most important sketch of the extent to which the human remains seized by an inhuman that is neither barbarous nor mystical, neither Caliban nor God. Psychoanalysis /pp 9-10/ would be a science of the soul (not of the subject), a paradoxical inquiry drawing us towards an inhuman that no Aufklärung could dissipate. Psychoanalysis, which Freud himself called "a Jewish science," Jewish despite its ambitions to make itself a science according to the protocols of Enlightenment, has made us recognize how the literary thing remains minor in its untranslatability into the universal language of the conscious human spirit. I have named Freud, but we must also mention Lacan. Less for his structuralist tendencies than for his exemplary insistence on an unconscious that is at the same time constitutive of consciousness and untranslatable into conceptual representation.

You may have already guessed that this is not a sad tale, even if I am relating to you the ruin of the general idea of humanity upon which the study of comparative literature was founded. I trust that you will have understood that the emergence of minor literature is not a recent occurrence; rather, every great literature is only stitched together with this minoritarian thread. And this because the work of comparative literature, for good or ill, has always taken place with regard to the question of translation. And this is not only because we've had some difficulty in translating "the task of the translator" as de Man has pointed out to us -- the impossibility of literary translation without loss has already been remarked upon many times[6]. Here is Derrida's summary in a translation by Alan Bass that resolutely substitutes the concept "materiality" for the more phenomenological fleshliness of Derrida's "corps verbal":

The materiality of a word cannot be translated or carried over into another language. To relinquish materiality: /pp 10-11/ such is the driving force of translation. And when that materiality is reinstated translation becomes poetry.[7] 
Alan Bass's wandering in translation is symptomatic of the error that enables translation. The material, the detail, the concrete, will be claimed as that which resists abstraction, resists alienating reduction to a universally exchangeable value. Yet, in a repetition of the error that dogs all of Roland Barthes's writing on the vraisemblable or "reality effect", the detail does not here resist signification, it signifies resistance. To put this another way, the resistance of details is subsumed: their seeming pointlessness always makes the same point. In order to translate, Bass (who is a very good translator and always makes the right mistakes) replaces the body with an abstract concept (materiality) that signifies resistance to signification, to abstraction, and to conceptualization. To testify to the differend is to struggle to keep that resistance open, not to signify it. It involves thinking of matter not as a substance, but as a diffuse series of ungraspable elements that abstract structures seek to organize conceptually. Matter resists the concept: to think matter as substance, as the rough --in a masculinist tradition that stretches from Milton to Stalin and Stakhanov-- is to make of matter a meaning. Matter cannot remain the other of conceptual thought if the triumph of matter would find it elevated to a concept. The latter is a somewhat Hegelian Marxist story in which the struggle of materialism would be to find the right concept for matter and so usher in the dictatorship of the proletariat as the meaning of matter. If I say that poetry is untranslatable and yet must be translated, it is because poetry is a working with the matter of words, an attempt to evoke the unthought in thought itself: the resistance of matter that any abstract or universal concept of "materiality" would erase. Bass, who wants Derrida to be liked by his Althusserian friends, is very keen for Derrida to be elaborating just such a theory of the materiality of language.

/pp 11-12/

It is of course no coincidence that this error arises around the recognition that the translation of poetry is a contradiction in terms. Errors of translation don't occur incidentally but are intrinsic to its structure, to the very idea of translation as the erasure of linguistic specificity, as a means of privileging the signified at the signifier's expense. But this old logocentric history has only resulted in the demand for poet translators, masters capable of dominating the specificity of at least two languages. Our loss of faith in their capacity for horizontal translation between national languages proceeds from the awareness of a vertical impossibility in translation. A sense of signifieds inseparable from their mode of expression and thus untranslatable, of signifieds which are not signifieds, so to speak --be they those of the unconscious, be they those of languages "foreign" to the European structure of representation. Here we might point to Freud's remarks in The Interpretation of Dreams on the difficulty of attaching words to the rebus like pattern of the dream text, or to Roland Barthes' meditation on translation in The Empire of Signs. 
If the modernist project of comparative literature was a translation of all languages into the language of the general idea of humanity, an explicitly secular work to redress the loss at Babel, it is not by chance that this project should now be at a loss in the face of the literature understood as the encounter of language with the untranslatable. On the contrary, the general idea of humanity was always already that of a Europe. Yet this Europe which was to have been the result of an enormous labor of translation was itself nothing more than a work of translation. If we take as an example Auerbach's Mimesis, Auerbach who deserves the title of stage-manager of the drama of European literature awarded by his editors at Minnesota, we find a history of Europe which expresses itself by the figure of translation itself, translatio imperii[8]. The "original" European culture was never anything more than the product of /pp 12-13/ a work of translation: the transport of Europa on a bull's back, the translation of Greece by the Roman military, of the Roman Empire by the Christian Humanist Renaissance, of the Italian Renaissance by German historians struggling against the northern fog of the nineteenth century, by Auerbach and Panofsky struggling to retranslate Europe from diaspora in the aftermath of the Holocaust. European literature has always retained a certain constitutive minority, in that the completion of translation that should mark its majority, the arrival of the great literature of humanity itself, cannot ever free itself from translation. The idea of Europe which should be the unified result of translation is never anything but the figure of translation repeated and thus disseminated: marked by translation and its difficulties at the origin, before any translation. At its beginning lies not a single origin, but at least two, and a journey between: a discursive archipelago perhaps --a periplum rather than a populum. National Socialism is the failure to recognize this, and hence Benjamin's insistence on the Task of the Translator as "a provisional way of coming to terms with the foreignness of languages" in the face of the claim for a People[9]. This misrecognition arises again as the failure of Europe to think community as anything other than a super-state: a further attempt to restrict difference to legally registered and policed frontiers. And let me be clear, the alternative is not an undifferentiated or unified humanity: Esperanto will always have been the language of a foolish hope, a failure to recognize that Aeneas founded a new world order on the plains of Latium only after a journey across to there: a trans-Latium if you will.

And herein lies the importance of comparative literature, its impossible project: to translate into one language the heterogeneity, the difference, of translation as such. Europe cannot ever /pp 13-14/ be born out of translation, being itself nothing more than a figure for translation, a figure that deconstructs any completed representation: a process figured in James Joyce's passage from Ulysses to Finnegan's Wake. A work of translation which always remains to be done, the tradition of comparative literature, at its best, has never been content to consider translation as an operation that is secondary or incidental to reading. In this manner, translation becomes the figure of the double-bind of reading, necessary but impossible. Whence proceeds the history of comparative literature as dwelling place of deconstruction: unheimlich hearth of literature understood as the exercise 
of a language foreign to itself, as the impossible but necessary work of translation within a language, the minor work of a Kafka, for example.

If comparative literature retains its importance for us as that which poses the problem of translation, we would perhaps do better to speak of "differing literatures" of a persistent foreignness to every attempt at unification, whether integrationist or exclusive. In this way, one might work out another politics of reading, a politics which is not one. Not a politics, that is, within the modernist project of a political criticism, of a universal language of political significance into which one might translate everything according to its effectivity. This seems to me to be the danger of a certain political consciousness in contemporary criticism which poses the political as the bottom line, the last instance where meaning can be definitively assessed. Deconstruction has the merit of reminding us that such a political critique is not so much an iconoclastic break with traditional critical practices as their apotheosis. Historical materialism, from this point of view, takes on a distinctively idealist cast. If Frederic Jameson tells us to always historicize, the $<<$ always $>>$ renders events indifferently historical[10].

Rather than positing history as a universal language, in a move complicit with the contours of imperialism, I'd like /pp 14-15/ to allude once more to Lyotard's The Differend, where he sketches a resistance to capitalism by means of the analysis or reading of phrases. If capitalism ascribes hegemony to the economic genre, to the rule of exchanges and of the market, it presupposes that all objects are capable of being exchanged because they all speak the same language --that of abstract time. Capitalism, in this analysis, submits each aspect of life to this kind of translation, translating the real time of work into the abstract time of wage labor, for example.[11] A resistance to capitalism would involve the evocation of an untranslatable time, the time that Lyotard calls that of the event, of the "is it happening?" against the hegemony of the economic genre.

Following this process, I'd like to propose reading as an act of resistance insofar as it may be the becoming minor of great literature, the passage from comparison to differentiation. Now Lyotard doesn't talk very much about the word "reading" except in a negative sense in Discours, Figure. He prefers to speak of "rewriting" to indicate that paying attention to texts must be considered as an act with a temporality, as a practice rather than a simple recognition of their signification. Thus, for instance, his retreat from the term "postmodern" in favor of speaking of either "the predicament of being in modernity" or "rewriting modernity" proceeds from the temptation to understand the postmodern as some kind of pure posiion at which reading becomes possible in an abstract sense. This is to say, that the postmodern has unsurprisingly been thought as the latest modernity. A pragmatic sense of the word "reading" insists upon reading as the predicament of action in the light of being addressed by texts that come from elsewhere, texts that we can neither ignore nor simply speak to -- texts to which we must reply 
but which cannot be finally answered. My interest in preserving the word "reading" in the place of Lyotard's use of "philosophy" to name the genre which "has as its rule the attempt to /pp 15-16/ discover its rule"[12] flows from my desire to develop deconstructive literary criticism as an "ethics of reading" rather than a theoretical method. To deconstruct is not to discover what is or is not in a text or how a text reflects or fails to reflect its context. Rather, it's to push a text to the point where it becomes an event, an occurrence that displaces any preexisting rule that might have allowed its recognition or comprehension, its translation into a determinate and exchangeable signification. This means that the ethical turn in deconstruction has nothing to do with moralism. To do justice to a text does not mean to remain faithful to its content or to make of its form a content to which the critic might be faithful. On the contrary, it's the work of listening to how texts are torn away from themselves by a difference which they seek to express but cannot. These aporias are not simply contradictions (there will be no reconciliation with Althusser), nor are they merely false. Rather, they are of the order of the Freudian lapsus, silences which speak of heterogeneous investments of desire, of the incommensurability of the differend --"the unstable state and the instance of language where something which should be able to be put into phrases cannot yet be"[13]. De Man's apparent failure to read Freud is perhaps what condemns American deconstruction to reduce this difference to an epistemological error.

I have spoken of Auschwitz, which names the terror of European humanism, the simultaneous summit of its rationality (all those train time-tables) and of its irrationality. This paradox produces the eerie kitsch that characterizes, for example, the interviews with Eichmann - --the horrendous parody of a bank clerk's pride in the efficiency of mass extermination. Adorno's remarks in Negative Dialectics on the extent to which all attempts to explain Auschwitz are of the order of the music with which SS guards used to drown out the screams of their victims pose the problem of /pp 16-17/ Auschwitz most clearly[14]. This must not have been just another moment in history: to remember it historically is to forget its horror just as effectively as if we consign it to oblivion. How are we to come to terms with an event for which no atonement is possible? How are we to listen to the silence of exterminated victims, to testify to their suffering when survival brings with it an inexpungible and speechless guilt? How are we to preserve the memory of victims whose singular victimization lies in their having been reduced to silence? To make them speak is already to forget that horror: how then can we read and write after Auschwitz, perform a work of testimony that keeps open their silence rather than making them speak? A writing that animates the differend between historical voice and historical silence is required: a writing that listens to the silence that tears apart the heart of Europe and witnesses to the terror that haunts the idea of European unity.

De-nationalizing literature, performing a reading that struggles against the violence and exclusion of literary nationalisms, is not a process that should seek legitimation from a greater unity, from a general idea or universal 
language of humanity. Such a legitimation is always the terroristic suppression of the aborigine or the jew: of the persistently local or minoritarian element. We should not simply aim to overcome existing borders and frontiers between people in the name of an undifferentiated humanity. Borders exist not so much to mark differences as to regulate them, to gather them into expected concentrations so as to permit their policing and allow for economic translation (trade). Thus the process of cultural stereotyping against which so much critical effort is directed is misunderstood if we think that it works to make everyone the same. That is palpably not the case; rather stereotyping works like national borders; to make people differ in the same way ---to think their difference under a universalizing logic of identity. De-nationalizing does not mean abolishing difference but abolishing the myth of identity that regulated and policed difference upholds. Thus, what is required is a reading of the frontiers and borders that are at /pp 17-18/ work within and against the pretensions to "greatness", to majority, of any national literature. That is to say, a finding of the minor and the evocation of its differend where it is not expected.

\title{
Université de Montréal
}

Département de Littérature Comparée

\author{
C.P. 6128, Succ. A - Montréal - QC H3C 3J7 - Canada
}

Surface Page d'Acceuil/Home Page

[1] Deleuze et Guattari, Kafka: Pour Une Littérature Mineure, (Paris: Minuit, 1975).

[2] Paul de Man, Blindness and Insight: Essays in the Rhetoric of Contemporary Criticism, 2nd ed., rev. Introduction de Wlad Godzich. Theory and History of Literature, tome 7. (Minneapolis: University of Minnesota Press, 1983).

[3] Pour de plus amples renseignements sur ce film, voir mon article "Pagans, Perverts and Primitives: Experimental Justice in the Age of Capital" dans Judging Lyotard, éd. Andrew Benjamin (London \& New York: Routledge, 1992).

[4] Lyotard, Heidegger et "les juifs" (Paris: Galilée, 1988), pp. 13-14. 
[5] A propos du "ghost-writing" il faut signaler le livre de Nicholas Royle, Telepathy and Literature (Oxford: Basil Blackwell, 1991 )

[6] Voir Paul de Man, "Conclusions: Walter Benjamin's The Task of the Translator" dans The Resistance to Theory, Theory and History of Literature, Tome 33 (Minneapolis: University of Minnesota Press, 1986).

[7] Jacques Derrida, L'écriture et la différance (Paris: Points, 1979), p. 312.

[8] Voir Eric Auerbach, Scenes from the Drama of European Literature, Theory and History of Literature, tome 9 (Minneapolis: University of Minnesota Press, 1984).

[9] Walter Benjamin <<Die Aufgabe der Übersetzers $>>$, Schriften Bande IV, teil 1, éd. Tillman Rexroth, (Frankfurt am Main: Suhrkamp, 1972) p. 14:

Damit is allerdings zugestanden, daB alle Übersetzung nur eine irgendwie vorläufige Art ist, sich mit der Fremdheit der Sprachen auseinanderzusetzen.

[10] Frederic Jameson The Political Unconscious (Ithaca: Cornell University Press, 1981), p.9.

[11] Voir Jean-François Lyotard, Le Différend (Paris: Minuit, 1983), p. 254, \#250.

[12] Lyotard, Le Différend, p. 95, \#98.

[13] Lyotard, Le Différend, p. 29, sec. 22.

[14] Theodor Adorno, Negative Dialectics, p. 325. 